\title{
Isolation and screening of dye decolorizing bacteria from industrial effluent
}

\author{
Mayur Gahlout*, Poonam Chauhan, Hiren Prajapati, Suman Saroj, Poonam Narale \\ KBS Commerce and Nataraj Professional Sciences College, Vapi, Gujarat, India.
}

\begin{tabular}{l}
\hline ARTICLE INFO \\
\hline Article history: \\
Received on: $25 / 04 / 2017$ \\
Accepted on: $17 / 06 / 2017$ \\
Available online: $14 / 08 / 2017$
\end{tabular}

Key words:

Acid Maroon V dye,

Microorganisms,

Decolorization, Medium

optimization.

\begin{abstract}
Acidic dye is a dye which is salt of a sulphuric, carboxylic or phenolic organic acid .It is used on wool, other animal fibers and some manufactured fibers. These dyes when disposed into the environment causes pollution and serious irreversible damage to the ecosystem. In the present study various sample is collected from effluent of industry in the Vapi region. Four isolates SP1, SP2, SP3 and SP4 found to be effective decolorizer of Acid Maroon V dye. Among these isolate, SP4 shows maximum decolorization.
\end{abstract}

\section{INTRODUCTION}

A dye or dyestuff is usually a coloured organic compound or mixture that may be used for imparting the colour to a substrate such as cloth, paper, plastic, or leather in a reasonable permanent manner."A dye may be defined as an organic compound containing chromophore and auxochrome group linked to the benzene ring." A chromophore group imparts property of colour. Compounds of benzene containing chromophore radicals are called chromogensss. Such a compound, even though coloured, is not a dye, because it possesses nor affinity for, nor the ability to unite with the fibers and tissues [1].

Dyes are an important class of synthetic organic compounds, widely used in textile, leather, plastic, cosmetic and food industries and are therefore common industrial pollutants. Dyes may also significantly affect photo synthetic activity in aquatic life by reducing light penetration intensity and may also toxic to some aquatic flora and fauna which is a salt of a sulphuric, carboxylic or phenolic organic acid [5]. The salts are often sodium or ammonium salts. Acid dyes are typically soluble in water. Some acid dyes are used as food colorants [6]. Biodegradation processes are environmentally, friendly and cost

* Corresponding Author

Email: mayur_nu@yahoo.com effective and are also alternative to chemical decomposition process. Microorganism plays a very important role in the biodegradation and mineralization of these dyes which is of great significance [3, 4]. In present study screening for dye decolorization bacteria was performed using various dye contaminated sample.

\section{MATERIALS AND METHODS}

\subsection{Dye and chemicals}

Dye such as Acid Maroon V, Colorent Red BS, Carzol Brilliant Blue RN, Red FRR, T Blue M5G, and Acid Red-2 were collected from Narayan Processor Pandesara, Faze limited chemical industries Surat. Glucose, Ammonium Sulphate, $\mathrm{NaCl}$, $\mathrm{K}_{2} \mathrm{HPO}_{4}, \mathrm{KH}_{2} \mathrm{PO}_{4}$, and $\mathrm{MgSO}_{4}$ All media components and chemicals used in the study were of high purity and analytical grade.

\subsection{Isolation and Screening of Dye Decolorizing Microorganisms}

Isolation of dye decolorization was carried out by inoculating $1 \mathrm{~g}$ of soil sample in $100 \mathrm{ml}$ of MSM medium (Mineral Salt Medium containing (g/l) glucose5.0; ammonium sulphate $1.0 ; \mathrm{K}_{2} \mathrm{HPO}_{4} 6.0 ; \mathrm{KH}_{2} \mathrm{PO}_{4} 1.0 ; \mathrm{MgSO}_{4} 0.1 ; \mathrm{NaCl} 5.0 ;$ ) containing $100 \mathrm{ppm}$ of dye into $250 \mathrm{ml}$ of Erlenmeyer flask. 
The inoculated medium was incubated at $30^{\circ} \mathrm{C}$ under static condition and observed for the dye decolorization. After decolorization, the enriched media is serially diluted and spreaded on dye containing plate. The isolates obtained were purified by subculturing on nutrient agar plates. All the isolates were studied for decolorization on dye containing plate as well was in liquid medium (MSM). The isolate giving better decolorization was selected for further study. The pure form of isolated bacteria was streaked on nutrient agar slants and incubated at $30^{\circ} \mathrm{C}$ for 48 hours. The pure culture is then stored in refrigerator at $4{ }^{\circ} \mathrm{C}$ and subcultured periodically.

\subsection{Decolorization Experiment \\ 2.3.1 Inoculum Preparation}

The preserved culture was transferred in $100 \mathrm{ml}$ Erlenmeyer flask containing $50 \mathrm{ml}$ nutrient broth. The flasks were incubated at $30^{\circ} \mathrm{C}$ for 24 hours. The freshly grown 24 hours old culture with 1.0 O.D. at $600 \mathrm{~nm}$ is used as inoculum for decolorization study.

\subsection{Dye Decolorization Study}

The sterilized medium was inoculated with $100 \mathrm{ppm}$ dye and $1 \%(\mathrm{v} / \mathrm{v})$ of 24 hours old culture. The inoculated flask was allowed to incubate at $30^{\circ} \mathrm{C}$ for 72 hours under static condition. The sample was withdrawn at regular time interval and supernatant was subjected to centrifuge at $5,000 \mathrm{rpm}$ for 20 minutes and decolorization was determined.

\subsection{Analytical method for dye decolorization study}

Decolorization was quantitatively analyzed by measuring the absorbance of the supernatant at maximum absorption wavelength, $\lambda \max$ of respective dyes. Decolorization was calculated by using the equation:

$$
\% \text { Decolorization }=(\mathrm{A}-\mathrm{B}) / \mathrm{A} \times 100
$$

Where, A is initial absorbance of control dye (initial absorbance) and $\mathrm{B}$ is observed absorbance of degraded dye (final absorbance).

\subsection{Time course study}

The time course was done by inoculating the MSM medium with $100 \mathrm{ppm}$ dye, $1 \%$ inoculum and incubated at $30^{\circ} \mathrm{C}$ for 72 hours under static condition. The sample were withdrawn from both medium flasks at interval of 12 hours and centrifuged at $5,000 \mathrm{rpm}$ for 20 minutes and supernatant was used to determining decolorization.

\subsection{Effect of medium composition on dye decolorization process}

Different medium were used for evaluation of decolorization and each medium $(100 \mathrm{ml})$ were inoculated with $100 \mathrm{ppm}$ dye, $1 \%$ inoculums and incubated at $30^{\circ} \mathrm{C}$ for 48 hours under static condition. After 48 hours of incubation, $5 \mathrm{ml}$ of sample were withdrawn from each flask and centrifuged at 5,000 rpm for 20 minutes. The supernatant was used for determining decolorization. The medium used in present study are as follows:

Medium 1: MSM (Mineral Salt Medium) containing $(\mathrm{g} / \mathrm{L})$ glucose 5.0; ammonium sulphate $1.0 ; \mathrm{K}_{2} \mathrm{HPO}_{4}$ 1.0; $\mathrm{KH}_{2} \mathrm{PO}_{4} 1.0 ; \mathrm{MgSO}_{4} 0.1 ; \mathrm{NaCl} 5.0$

Medium 2: NDM (Normal Decolorization Medium) containing $(\mathrm{g} / \mathrm{L})$ glucose 2.0; ammonium sulphate 2.5; yeast extract 2.5; $\mathrm{KH}_{2} \mathrm{PO}_{4} 5.0 ; \mathrm{MgSO}_{4} 0.5 ; \mathrm{CaCl}_{2} 0.13$

Medium 3: BSM (Basal Salt Medium) containing (g/L) $\mathrm{NH}_{4} \mathrm{Cl} \quad 0.5 ; \mathrm{K}_{2} \mathrm{HPO}_{4} \quad 1.2 ; \quad \mathrm{KH}_{2} \mathrm{PO}_{4} \quad 0.4 ;$ glucose $0.2 ;$ peptone 0.2

Medium 4: BHM (Basal and Haas Medium) containing (g/L) $\mathrm{MgSO}_{4}$ 0.2; $\mathrm{CaCl}_{2} 0.02 ; \mathrm{K}_{2} \mathrm{HPO}_{4}$ 1.0; $\mathrm{KH}_{2} \mathrm{PO}_{4}$ 1.0; $\mathrm{NaNO}_{3}$ 1.0; $\mathrm{FeCl}_{3} 0.05$

Medium 5: BMM (Basal Mineral Medium) containing $(\mathrm{g} / \mathrm{L}) \mathrm{NaCl} 7.0 ; \mathrm{CaCl}_{2} 4.0 ; \mathrm{MgSO}_{4} 2.0 ;$ glucose 10.0; yeast extract 1.0

\section{RESULTS AND DISCUSSION}

\subsection{Isolation and screening of dye decolorizing bacterial isolates}

Various sample from Faze chemical effluent, Dye contaminated soil, and Sludge sample was used to isolate dye decolorizing microorganisms. A total of 15 bacterial strains were isolated and purified by subculturing on nutrient agar plates. The morphological and cultural characteristics of the bacterial isolate are shown in Table 1. All the isolated cultures were further screened for dye decolorization in liquid medium. The screening of all the isolate for dye decolorization is shown in Table 2. The result obtained shows that maximum decolorization $(76.07 \%)$ of Acid Maroon V dye by bacterial isolate SP4 was obtained after 48 hours of decolorization process. Patel at al., (2016) reported maximum decolorization (87.33\%) of Red H8B dye by isolate R5 within 72 hours of incubation.

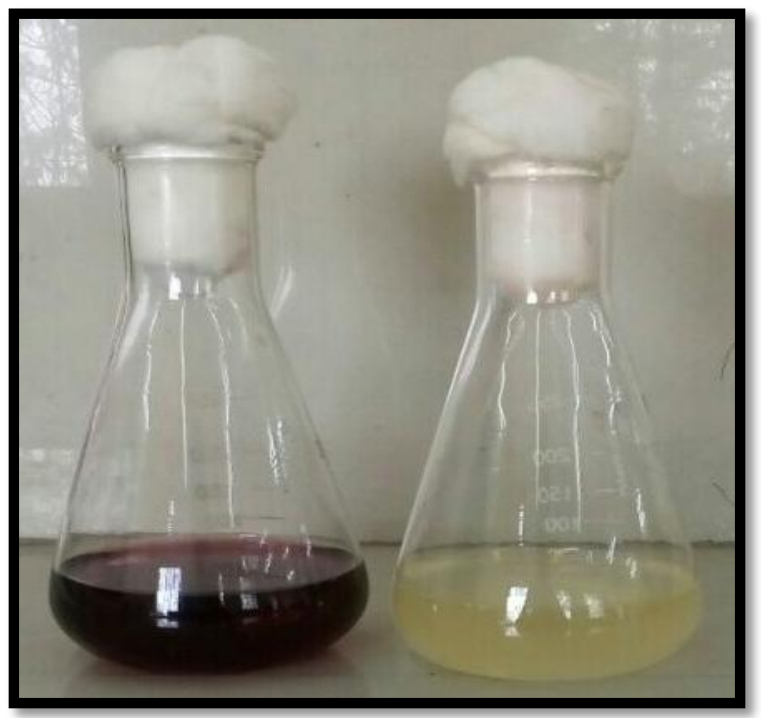

Fig. 1: Decolorization of Acid Maroon V dye by isolate SP4 
Table 1: Morphological and cultural characteristics of isolates.

\begin{tabular}{|c|c|c|c|c|c|c|}
\hline Sr. No & Sample & Isolate & Colony characteristic & Gram staining & motility & $\begin{array}{l}\text { Capsule } \\
\text { staining }\end{array}$ \\
\hline $\mathbf{1}$ & Faze chemical industry soil & SP1 & Medium, circular, entire, smooth, moist, opaque & Gram positive cocci & Non-motile & Positive \\
\hline 2 & Faze chemical industry sludge & SP2 & Large, round, entire, smooth, mucoid, opaque & Gram negative rods & Non- motile & Negative \\
\hline 3 & Faze chemical industry soil & SP3 & Medium, round, entire, smooth, moist, opaque & Gram positive cocci & Non-motile & Negative \\
\hline 4 & Faze chemical industry sludge & SP4 & Small, round, smooth, irregular, opaque & Gram positive rods & Motile & Negative \\
\hline 5 & Polyster chemical industry soil & SP5 & Large, round, irregular, moist, opaque & Gram positive cocci & Non- motile & Negative \\
\hline 6 & Polyster chemical industry soil & SP6 & Medium, irregular, smooth, butyrous, opaque & Gram positive thin rods & Non-motile & Positive \\
\hline 7 & Polyster chemical industry sludge & SP7 & Small, round, entire, smooth, translucent & Gram positive cocci & Motile & Positive \\
\hline 8 & Faze chemical industry soil & SP8 & Large, round, entire, smooth, opaque & Gram negative short rods & Non-motile & Positive \\
\hline 9 & Polyster chemical industry soil & SP9 & Small, round, circular, mucoid, opaque & Gram negative short rods & Non-motile & Negative \\
\hline 10 & Faze chemical industry soil & SP10 & Medium, irregular, smooth, butyrous, opaque & Gram positive cocci & Non-motile & Positive \\
\hline 11 & Dye chemical industry soil & SP11 & Medium, round, entire, smooth, translucent & Gram positive rods & Motile & Negative \\
\hline 12 & Dye chemical industry sludge & SP12 & Large, irregular, smooth, butyrous, opaque & Gram negative rods & Non-motile & Negative \\
\hline 13 & Polyster chemical industry soil & SP13 & Small, circular, entire, smooth, opaque & Gram negative short rods & Non-motile & Positive \\
\hline 14 & Faze chemical industry soil & SP14 & Medium, entire, moist, translucent, & Gram positive cocci & Non-motile & Positive \\
\hline 15 & Dye chemical industry sludge & SP15 & Large, round, irregular, mucoid, opaque & Gram negative rods & Non-motile & Negative \\
\hline
\end{tabular}

Table 2: Screening of bacterial isolates for dye decolorization (\%).

\begin{tabular}{|c|c|c|c|c|c|c|c|}
\hline \multirow{2}{*}{ Sr. No } & \multirow{2}{*}{ Isolates } & \multicolumn{6}{|c|}{ Decolorization (\%) } \\
\hline & & Acid maroon v & Colorent Red Bs & Carzol Brilliant Blue RN & Red FRR & T Blue M5G & Acid Red-2 \\
\hline 1 & SP1 & 27.09 & 11.23 & 12.67 & 24.76 & 54.89 & 19.89 \\
\hline 2 & $\mathrm{SP} 2$ & 19.45 & 34.15 & 40.34 & 30.66 & 66.65 & 58.90 \\
\hline 3 & SP3 & 54.12 & 49.19 & 45.45 & 37.87 & 59.87 & 24.36 \\
\hline 4 & SP4 & 76.07 & 48.47 & 68.76 & 70.37 & 62.26 & 68.76 \\
\hline 5 & SP5 & 68.90 & 55.32 & 63.36 & 59.00 & 70.00 & 70.54 \\
\hline 6 & SP6 & 23.32 & 67.34 & 58.56 & 63.86 & 64.28 & 57.65 \\
\hline 7 & SP7 & 65.87 & 56.23 & 60.00 & 62.98 & 69.43 & 61.32 \\
\hline 8 & SP8 & 67.32 & 30.54 & 63.43 & 63.87 & 31.67 & 39.98 \\
\hline 9 & SP9 & 9.25 & 21.11 & 30.45 & 42.76 & 54.23 & 26.43 \\
\hline 10 & SP10 & 54.43 & 58.76 & 69.45 & 63.23 & 58.71 & 61.66 \\
\hline 11 & SP11 & 59.87 & 55.43 & 58.54 & 65.76 & 51.43 & 59.32 \\
\hline 12 & SP12 & 8.32 & 6.1 & 13.12 & 32.11 & 41.98 & 21.54 \\
\hline 13 & SP13 & 66.52 & 64.69 & 61.62 & 56.43 & 62.55 & 59.25 \\
\hline 14 & SP14 & 34.24 & 39.54 & 49.34 & 38.34 & 37.25 & 40.65 \\
\hline 15 & SP15 & 59.35 & 53.54 & 55.95 & 41.12 & 50.43 & 58.65 \\
\hline
\end{tabular}

\subsection{Optimization of cultural condition for dye decolorization study}

In present study a bacterial isolate 15 selected as reference culture and Acid Maroon V dye as reference dye for the dye decolorization study.

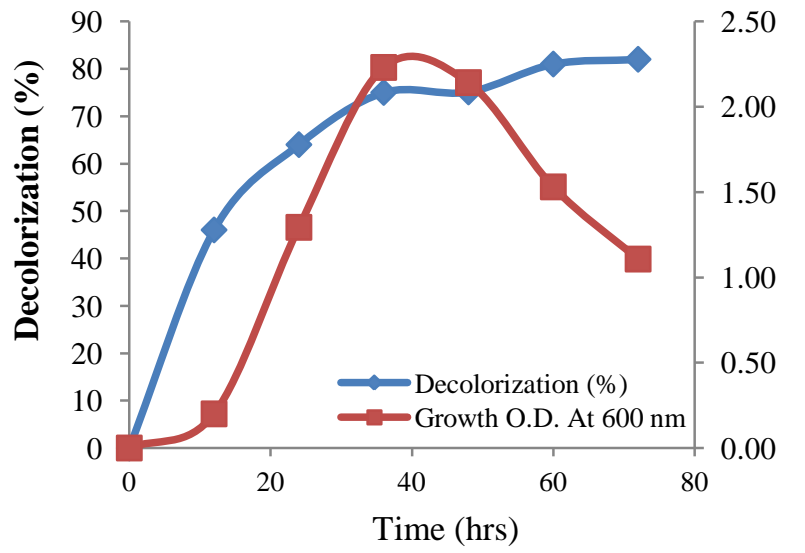

Fig. 2: Time course study.

\subsection{Effect of incubation period on dye decolorization}

The decolorization of Acid Maroon V dye was determined at various incubation time (i.e. 0, 72 hours). The result obtained shows that decolorization was increased as incubation time increased and maximum decolorization was obtain at 48 hours of incubation $(75.11 \%)$, however, further incubation of decolorization flask does not enhance the decolorization process.

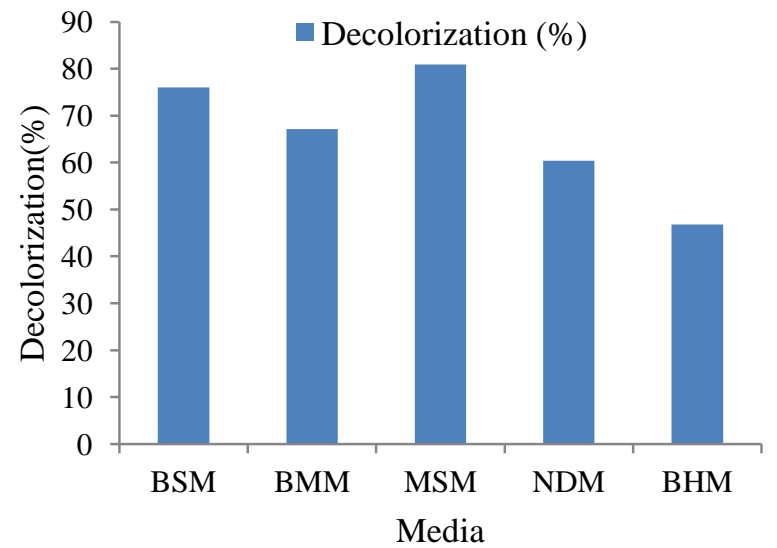

Fig. 3: Effect of different medium composition on dye decolorization.

\subsection{Effect of medium composition on dye decolorization}

In present study decolorization of dye was studied using various media composition such as NDM, BMM, BHM, MSM, and BSM. The result obtained shows that after 48 hours of 
incubation at $30^{\circ} \mathrm{C}$ under static condition, the percent decolorization obtained was $60.04 \%, 67.09 \%, 48.08 \%, 91.00 \%$ and $76.00 \%$ of NDM, BMM, BHM, MSM, and BSM respectively. The MSM medium gives maximum decolorization, thus MSM medium was selected as reference medium for further decolorization study. Patel et al reported MSM medium for $88.60 \%$ decolorization of Red H8B dye by isolate R5.

\section{SUMMARY AND CONCLUSIONS}

The present study reveals that the isolate SP4 showed consistent decolorization and degradation of textile dye (Acid Maroon V) throughout the study and could be effectively utilized for the treatment of textile effluent containing high concentration of dyes before discharge into the environment.

\section{ACKNOWLEDGEMENT}

The author gratefully acknowledges Dr. Mayur Gahlout for guidance. Sincere thanks to Dr. Poonam B. Chauhan (Principal of Institute), Trustee A.K. Shah and Asst. Prof. Hiren Prajapati for all their support and facility in carrying out the research work.

\section{Financial support and sponsorship: Nil.}

Conflict of Interests: There are no conflicts of interest.

\section{REFERENCES}

1. Gahlout M, Gupte S, Gupte A. Optimization of culture condition for enhanced decolorization and degradation of azo dye reactive violet 1 with concomitant production of ligninolytic enzymes by Ganoderma cupreum AG-1. Biotechnology. 2013; 3(3):143-152.
2. Patel. Evaluation of Process Parameters for enhanced decolorization and degradation of Red H8B dye by bacterial isolate R5. International Journal of Drug Research and Technology. 2016; 6 (2):87-95.

3. Lie TJ, Pitta T, Leadbetter ER, Godchaux W, Leadbetter JR. Sulphonates Novel electron receptor in anaerobic respiration. Archives of Microbiology. 1996; 166(2):204-210.

4. Khalid A, Arshad M, Crowly DE. Accelerated decolorization of structurally different azo dyes by newly isolated bacterial strains. Applied Microbiology Biotechnology. 2008; 78(2):361-369.

5. Franciscon E, Zille A, Dias, GF, Ragagnin de MC, Durant LR, Cavaco-Paulo A. Biodegradation of textile azo dye by A Facultative Staphylococcus arlettae Strain $\mathrm{VN}-11$ using a Sequential Microaerophilic/aerobic process. International Journal of Biodeterioration and Biodegradation. 2009; 63(3):280-288.

6. Daneshvar N, Khataee AR, Ghadim AA, Rasoulifard MH. Decolorization of CI Acid Yellow 23 solution by electrocoagulation process: Investigation of operational parameters and evaluation of specific electrical energy consumption (SEEC). Journal of hazardous materials. 2007; 148(3):566-572.

\section{How to cite this article:}

Gahlout M, Chauhan P, Prajapati H, Saroj S, Narale P. Isolation and Screening of Dye Decolorizing Bacteria from Industrial Effluent. J App Biol Biotech. 2017; 5 (04): 076-079. 